\title{
Muinín Catalyst - Exploring Future-ready Teaching and Learning
}

\author{
Anita McKeown ${ }^{1}$, Rebecca White ${ }^{2}$ \\ SMARTlab Skelligs ${ }^{1}$, Green Space Education ${ }^{2}$ \\ Ireland
}

\begin{abstract}
The world of education and work is changing at a rapid pace. It is crucial to prepare learners with 21 st century skills to prosper in a more globalised and digitalised society. We want young people to be wellrounded, articulate and confident, able to survive and actively engage in the future world they will find themselves in - an economic, political and technological landscape that is far different than the ones that their parents grew up in. But how do we do this effectively with the current education system that focuses on academic performance, to the detriment of skills development? How do we use the local to help shape and develop their views, experience and skills as global citizens? This paper considers these questions through the Muinin Catalyst project building on and our work to date: CoDesRes Environmental Protection Agency Funded research to develop a prototype, place-based STEAM toolkit for Transition Year. To date, the project is the only placebased STEAM (Science, Technology, Engineering, Arts and Maths) pedagogical approach to the SDGs and future-ready needs in Ireland. The paper outlines our initial trajectory and the context for the work, from CoDsRes to Muinín Catalyst project, a legacy project and the development of integrated curriculum resources designed for Transition Year, in Irish Education. The paper presents the aims and key skills illustrated through an example of the learning interventions using one of the current projects, Seeding Sustainability and its contribution to developing resilience, and reflections on the intervention by, teachers and students and concludes with our vision for the next stages.
\end{abstract}

\section{Introduction}

The world of education and work is changing at a rapid pace. It is crucial to prepare learners with $21 \mathrm{st}$ century skills to prosper in a more globalised and digitalised society. We want young people to be wellrounded, articulate and confident, able to survive and actively engage in the future world they will find themselves in, with an economic, political and technological landscape that is far different than the ones that their parents grew up in. This paper presents process of a place-based STEAM approach with the following questions:
- How do we do this effectively with the current education system that focuses on academic performance to the detriment of skills development?

- How do we use a place-based STEAM approach to help shape and develop their views, experience and skills as global citizens?

CoDesRes 2018-20 [1] was a two-year Environmental Protection Agency-funded project that sought to localise the Sustainable Development Goals through education and community contexts; SDG 4 (Quality Education), SDG 11 (Sustainable Cities and Communities), SDG 14 (Life Below Water) and SDG 15 (Life on Land). For the purposes of the education aspect of the research, we proposed to operate in Transition Year (TY), a unique opportunity in Irish Education. Transition Year (TY), is an optional oneyear programme, positioned between Ireland's exam cycles, the third year Junior Cycle and the fifth and sixth year, Senior Cycle. TY has no prescribed curriculum for this year and students get to experience a variety of activities, including some formal learning.

Implemented in 2004, Transition Year (TY) was designed around giving students life skills and incorporating a work experience program, with a mission to:

- promote the personal, social, educational and vocational development of pupils and;

- to prepare them for their role as autonomous, participatory and responsible members of society. [2]

Critiques of TY range from 'certain subject areas lacked substance and students were not being sufficiently challenged' [3] to 'doss year' [4], yet other reports have shown that students gain confidence, new skills [5] and higher points in the Leaving Certificate results [6]. CoDesRes and Muinín Catalyst, offer an opportunity to explore place-based STEAM learning interventions that align to the Sustainable Development Goals, which have also faced criticism. One key aspect of this criticism that has particular relevance for education is their offer of an approach to 'transforming the world without using transformative methods' [7]. 
In addition, there is no defined curriculum for TY with each school offering different experiences and approaches. Many teachers, who are also teaching the standard curriculum adopt various competitions, NGOs and Business programmes e.g. SEAI's One The Big Idea, Young Entrepreneur, or project modules e.g. St Vincent de Paul's Youth for Justice. These programmes offer interesting content and structure, however they are not developed as linked learning, with teachers working across disciplines. Often sitting within individual subject areas or foci they do not build the systemic thinking, necessary for the 21st Century by encouraging students to consider the relationship between social, economic or environmental factors.

Muinín Catalyst is underpinned by a unique eco co-design methodology trialled in London, Dublin and New Mexico, the permaCultural resilience praxis (pCr) [8]. Muinín Catalyst integrates Art and Design into the STEM learning through the $\mathrm{pCr}$ praxis and Design Thinking (see Figure 1). This project-based approach ensures that the learning crosses subjects and the social, economic or environmental considerations of the expression of their learning. CoDesRes' education resources were trialled as interventions into existing classes, $\mathrm{x} 3$ double classes per week, and as week-long intensives.

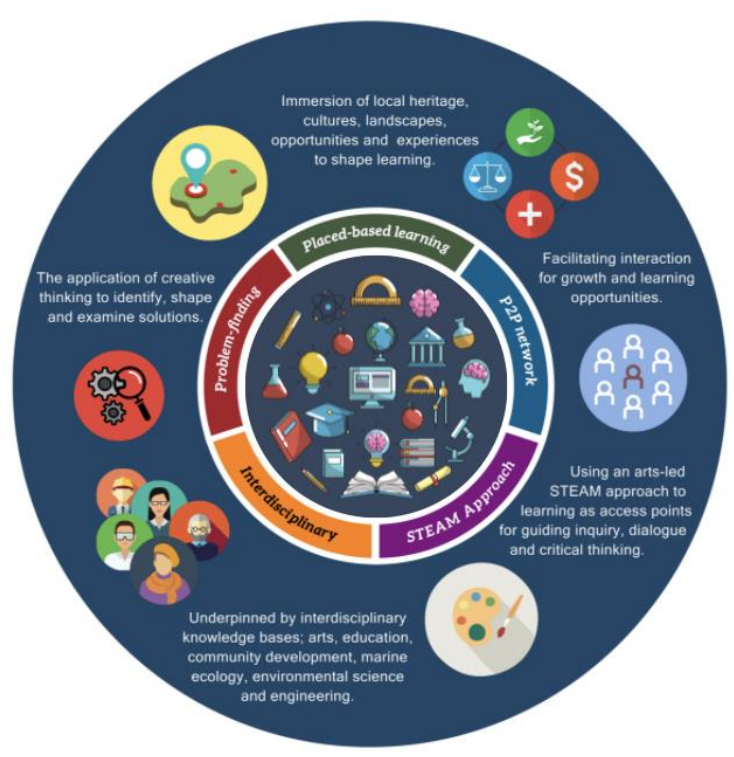

Figure 1. Muinín Catalyst Approach, 2020

Our initial findings are in line with the National Council for Curriculum and Assessment's National Review 2016-20) [9], and further verified by the intergovernmental, Organisation for Economic Cooperation and Development's (OECD) [10] report on the NCCA's review. The findings show an interest and need for citizenship and political education. Further, sustainability and climate change education and opportunities for interdisciplinary STEAM learning and application of knowledge have yet to be fully integrated into Ireland's education system. This is the void Muinín Catalyst hopes to address. As a legacy of the EPA-funded CoDesRes, the Muinín Catalyst project aims to explore learning interventions in South-West Kerry, Ireland to continue the development of a place-based STEAM curriculum for Transition Year that works with some of these critical 21st Century skills: collaboration, communication, presentation, design-thinking and critical-thinking.

\section{Muinín Catalyst}

The Muinín Catalyst programme aims to develop key skills through place-based learning that integrates STEAM education with project and inquiry-based learning with an ethical lens that forefronts social, environmental and economic justice. The Muinín Catalyst project is currently being trialled within Coláiste na Sceilge, a post-primary co-educational community college with an enrolment of 550 students. The school serves the Iveragh Peninsula, the largest peninsula in South West Ireland, based in County Kerry. The peninsula is also home to the Iveragh Gaeltacht (Gaeltacht Uíbh Ráthaigh), now one of the smallest in Ireland, historically it was one of the strongest. This demise is due in part to the lack of basic services, as one of the main reasons, cited more generally for the dramatic decline in the peninsula's population.

Working with Transition Year in the rural community of South-West Kerry enabled the Muinín Catalyst project's on-going work to develop the interventions initiated by CoDesRes. funded by Living Iveragh and CPL PLC, Ireland's largest recruitment agency. Living Iveragh's aim is to address the problem of rural depopulation through promoting Iveragh as a place of Research, Learning and Enterprise, and in collaboration with CPL, supported the Muinín Catalyst project to address the skills gap in the area and that CPL felt was missing for the future of work.

Recent research has shown that avenues least at risk from AI; education, research and development, ICT, green tech and environmental and culture-led sectors [11] require broadening post-primary students' understanding of STEAM opportunities. Muinín Catalyst's projects and their micro-modules introduce students to future growth areas; advanced manufacturing (Artificial Intelligence, 3D printing/additive manufacturing and rapid prototyping, and SMART economies amongst others) $[12 ; 13]$ Critical skills worked on through the programme include collaboration, communication, presentation, Design Thinking and critical thinking. Future ready skills that will support the students in a future as yet unwritten.

The aim of the project is to develop a nascent / beta 
place-based STEAM curriculum around the SDGs using the $\mathrm{pCr}$ praxis integrated with a Design Thinking methodology as a foundation. The aim is not simply to develop future-ready employees, but to ground the foundational skills that encourage enterprise and innovation and an ability to find the source of a problem and create solutions. In addition, given the rural context, the project also aims to introduce additional knowledge that may be more readily available within urban or suburban contexts.

The resources also introduce the concept of OpenSource culture and technology of which many of the students and teachers had little experience or knowledge. Open-Source Software originally referred to code and consequently technology that is designed to be modified and accessible. It has since become a movement and promotes a decentralised model of production and values to find new ways to solve problems in their communities and industries. Within the context of resilience, this offers additional tools that can be easily accessed with less reliance on expensive software and hardware. While not the focus of this paper it is worth noting as this is an important contribution to an approach to STEAM education that forefronts social, environmental and economic justice.

\section{Place-Based Steam}

The underpinning methodology: a specific placebased Design Thinking methodology, seeks to embed social, environmental and economic justice in its processes. This methodology creates learning interventions that are aligned to the United Nations Sustainable Development Goals and fill, what we believe, is a gap in the Irish second-level curriculum. The research also shows that it would be beneficial to introduce the development of these skills at a younger age in order to ensure their application at post primary level. Muinín Catalyst's focus is on connecting the learning interventions to the people, places and partnerships in the area. We look at how the development of skills with a local lens benefits not only the students and teachers participating in the intervention, but of those around them, for all of their futures.

As a pedagogical approach, STEAM places value on the arts for their creative methodologies and offers an approach to teaching and learning [14] 'that encourages and facilitates unorthodox methods and strategies'[15]. STEAM projects reflect contemporary interdisciplinary artistic concerns that are not bound by traditional media [or the production of objects] and utilise STEM skills and knowledge This has particular relevance for the needs of a 21 st Century, post-disciplinary education system as in STEAM education, learning occurs at the intersection of the five fields, Science, Technology, Engineering, Arts and Math (STEAM). This transforming how we know and investigate the world, with tangible modes of knowledge production [reference]. In addition, the arts can also disseminate STEM knowledge in a more accessible manner by 'making connections between diverse ideas and provoking unexpected conversations'[16].

A place-based approach is not specific to a geographic location; indeed, it provides a roadmap to learning grounded in 'local communities and contexts that is relevant and engaging and inquiry-based [17]. Through local and tangible opportunities for agency and autonomy, students gain a better understanding and appreciation of the world around them [17], which becomes a foundation for global connections. Within Muinín Catalyst's place-based approach the learning is interdisciplinary, exploring the complexity of a system of relationships, and offers a means to support and promote responsible and sustainable thinking and behaviour. This offers the foundation for connections and understanding between local, regional, national and global concerns, particularly if combined with opportunities for service learning through local partnerships and organisations beyond the school environment. From this perspective Muinín Catalyst look to support sustainable thinking and behaviour. Pedagogical research around place-based teaching and learning evidences that the links between, learning and stewardship [18] citizenship, [19], active engagement (insert reference).

As a pedagogical vehicle, place-based learning is an opportunity to situate other learning models; project-based, civic, service, professional and systemic models that integrate social and cultural, emotional, deep learning and 21 st century skills. This supports an ecosystem of learning opportunities, formal and informal, that through an increased attachment to place, enables students to invest locally and develop engagement that can support experiences and an ability to see links to their future and their position within their local area.

The Muinín Catalyst project extends the CoDesRes' resources with a series of projects that utilise linked learning and a three-phase process. The underpinning methodology, the $\mathrm{pCr}$ praxis is a situated methodology and therefore embeds the 'fusion of self, space and time' [20] this affords embodied understandings and enables a foundation for the physical and psychological experiences that develop the situated knowledge. Being embedded within the school context informed the development of the lessons and ultimately the toolkit, which have evolved through Muinín Catalyst.

The ROLE process is a four-phase approach outlined in the following phases (see Figure 2):

$\mathrm{R}$ - Relationships - Using an intensive audit tool to map cultural, economic, socio-political and environmental dynamics, the $\mathrm{pCr}$ praxis reveals 
relationships, resources and opportunities to help reconfigure and re-imagine an understanding of place.

O - The OBREDIM Audit log is a 3 phase tool that deepens the $\mathrm{pCr}$ audit undertaken in advance of developing any project or intervention broken down as follows:

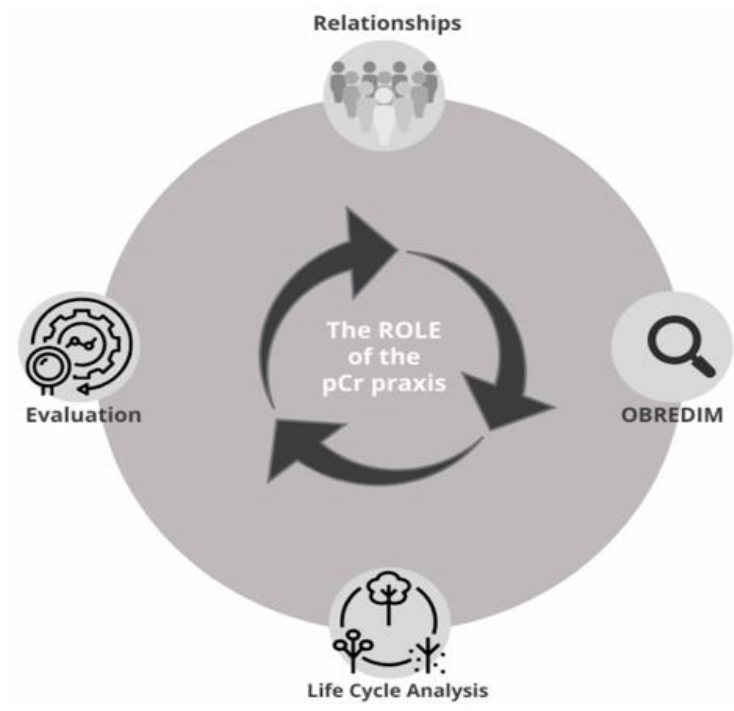

Figure 2. The ROLE of the $\mathrm{pCr}$ praxis [8]

- Phase 1: Observation - survey the landscape; Boundaries - find the edges and crossovers; Resources - audit the social, environmental and economic resources.

- Phase 2: Evaluation - consider the situation; Design - consider the logistics and plan the design.

- Phase 3: Implementation - put the audit into action; Maintenance - Sustain the process and work towards legacies.

L - Lifecycle Analysis - The framework offers a simple visual tool that embeds an eco-social commitment by addressing the full life cycle of a project and beyond.

E - Evaluation - The $\mathrm{pCr}$ toolkit includes an evaluative matrix, the Vital Signs Matrix (VSM), is based on the concept of the vital signs of a project and contributing to the vital signs of a project

The pCr praxis, is a unique arts-led situated approach to placemaking that has been adapted for education and leverages the momentum around the 2030 agenda. As a suite of tools, the pCr praxis was developed for place-based engagement that supports the user in project development, management and implementation. The tools are scaled to ageappropriate learning to develop the skills to observe aspects of the 'everyday' often overlooked or ignored, including inter-personal mapping, the rational, emotional as well as shared and distinct ways of knowing.

The Muinín Catalyst's projects use the $\mathrm{pCr}$ praxis, a unique eco-codesign methodology, place-based STEAM and Design Thinking to work towards an overarching project. At its simplest Design thinking is 'creative problem-solving' [21] that through a 'nonlinear, iterative process [can be used] to understand users, challenge assumptions, redefine problems and create innovative solutions to prototype and test'. [22] The tools are further embedded within the project's core Design Thinking module to facilitate practical applied learning, that teaches students the cognitive, strategic and practical processes by which design concepts are developed. The next section focuses on aspects of the resources through one of the projects Seeding Sustainability.

\section{Seeding Sustainability}

The Seeding Sustainability (SS) is one of a number of projects that have been devised to enable teachers to elect to undertake the whole project to create the place-based project / assessment piece or select micromodules, and or lesson plans to suit their timetables and interests. SS aligns to the following SDGs $2,3,4,11,12,13,14,15$ and 17), enabling the students to engage with the 2030 agenda through localised actions that enable them to consider and see the consequences of their impact. The integration of social, environmental, and equitable economic concerns within place-based STEAM education combined with Design Thinking develops local contributions to Ireland's SDG targets, that acknowledges more than human needs in tangible and meaningful ways.

The SS consists of seven module themes and 8 subject micro-modules. These are organised across three phases: Research and Development, Experimentation and Exploration and finally, Implementation.

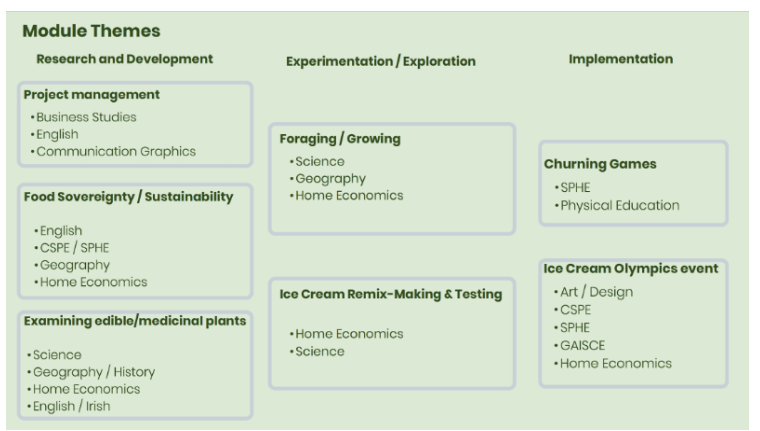

Figure 3. Seeding Sustainability

Original Module Plan, 2020 
The originally developed to realise The Ice Cream Olympics, a fun, food sovereignty project, the resources are built to adapt to a school or teacher's use or interests and suit the local context e.g. pollinator / rewilding projects or larger scaled horticultural / biodiversity projects. In this instance, the project's objective was the design and phase one implementation of a $1 \mathrm{KM}$ walking trail with linked, or pause points, with features that support social and environmental well-being for both the school and wider community. This was an initiated by the school, who have ambitions to become more of a community hub.

Within the Seeding Sustainability module, the five phases of Design thinking: Empathize, Define, Ideate, Prototype and Test, have been adapted in combination with the pCr tools to support students in a scaffolded process, lesson by lesson to design the trail. Bespoke learning activities are created to lead students through the learning process developing the foundational skills and understanding that are required. Developing empathic design skills through engagement with users' needs is the first step in the process. An adaptation of Stanford University's five chairs exercise that focuses on imaginary users of the trail, encouraging students to think of the users' needs (see Figure 4).

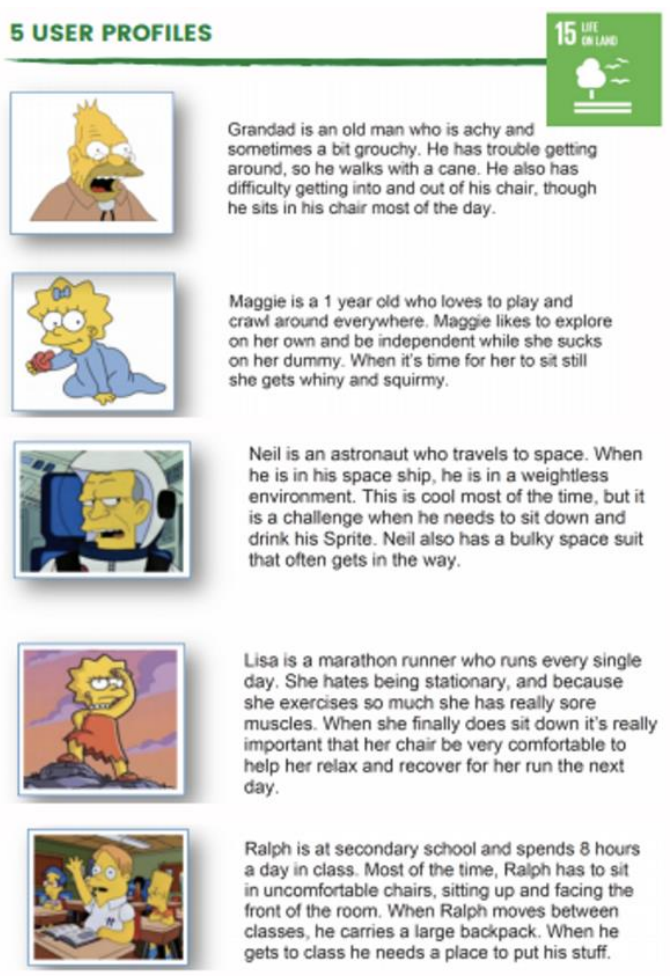

Figure 4. User Profiles 2020 adapted from Stanford school - 5 chairs

The User Profiles is scaffolded towards the needs of potential users and the students begin to integrate these concepts into their design ideas for different areas and nodes for the trail. Activities like this build the $\mathrm{pCr}$ and the Design Thinking methods into the lesson plans through practical exercises including outdoor learning e.g., mapping of the school grounds, surveying existing flora and the trail's environment.

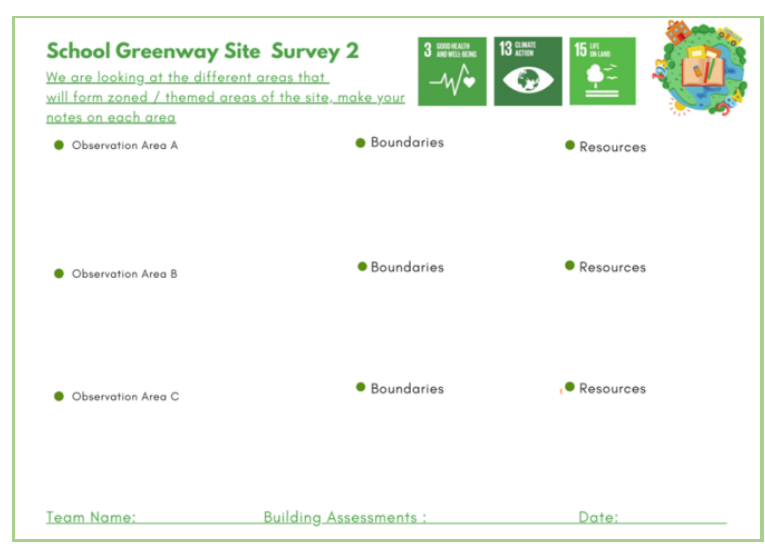

Figure 5. OBREDIM Audit Phase 1, 2020

The core team adapted the resources to suit the overarching project's new aim as well as facilitating emerging ideas from the students. This extending the experimentation and exploration phase to include additional design modules around foraging and growing e.g., hydroponic systems design, container gardening, raised beds and composting. The team developed worksheets, discussions, hands-on design activities, with resources on other related or supporting skills such as research skills, interviewing and media production. This process supported the students to take their ideas from paper into $3 \mathrm{D}$, by creating dioramas, a presentation or if preferred digital design drawings. When possible, local resources such as the physical aspects of the town and the peninsula, its communities of which the students are members and entrepreneurial or innovative examples are built into the lesson plans, with transferable recommendations. Within Seeding Sustainability, a local landscape architect worked with the core team, adding specific knowledge to the project, including landscape design and plant knowledge. This cross-pollination of knowledge and skills are necessary to address a local and global landscape and re-imagine and re-present place. This focuses the students' learning and solution-focused activities to address localised concerns through a 'real-world' project. Working through the Design Thinking process embeds transferable skills, to realise the project at hand and develop skills for a future that has challenges that are undefined.

The resources are scaffolded for both teachers and students to encourage confidence and competence in delivering and responding to new material and approaches, with the teacher facilitating learning and the students supported to develop skills for self- 
directed learning. The step-by-step learning process develops their ability to see the themes, issues and problems as more than a theoretical lesson and something that affects them and their community. This enables the learners to connect to the learning, their place and the world, as they are intrinsically motivated, kept engaged and are more invested. The module's interconnected topics across curriculum areas expands the students' knowledge and skills more creatively.

\section{Project Impact}

Project and linked learning are not facilitated within the national curriculum, however changes to the Junior Cycle curriculum has revised subjects, added short courses and practical assessments with a focus on literacy, numeracy and key skills, which will begin to impact on the Senior Cycle currently under review [8]. These findings were also reflected in our research and its approach to teaching and learning methods e.g. class discussions, peer learning, pair and group work including project work [8].

Seeding Sustainability was evaluated in a number of ways. Each class was evaluated using a 3-2-1 method: (three things they learnt, two things they would like to know more about, and one comment on their overall opinion of the class or improvements augmented with focus groups.
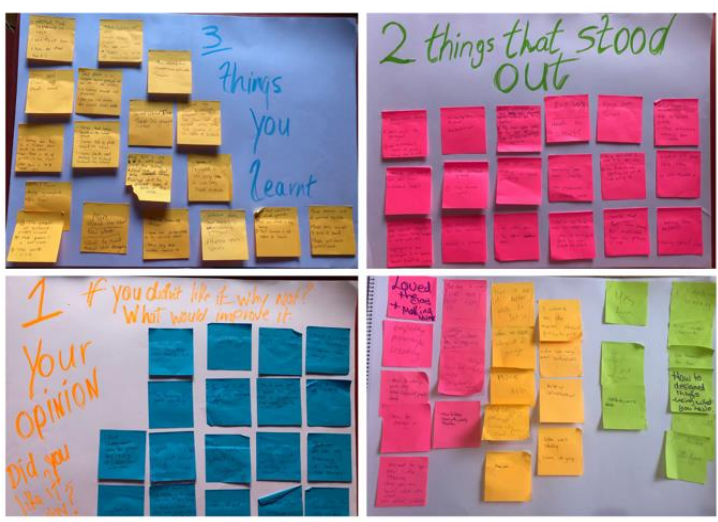

Figure 6. Examples of 321 evaluation, 2020

Examples of students' response, three things you learnt:

... Empathy, prototype, creativity.

... Design, needs for people, how to design using small places.

... How to design things using what you have.

Two things that stood out:
... Design is part of everything.

... Learning about native plants and their names and importance.

The final evaluation criteria, one thing about their opinion, encouraged students to say if they liked it and why and if not, one thing they would do to improve the lesson.

... It was very interesting and I learnt new things.

... Yes, it was good. I realised the school needs to be brightened up and needs to be looked after.

... Loved it, it was really interesting and I learnt new things.

School closure due to COVID-19 restrictions, meant that students ideas were unrealised, however the project will be continued next year with both existing students ideas as well as new ideas being developed by the $2021 / 2022$ cohort.

\section{Learner Support}

Collectively, the modules devised embed the pCr's praxis and Design Thinking: cognitive, strategic and practical processes by which design concepts are developed using the $\mathrm{pCr}$ praxis to create an approach to place-based STEAM as access points for supporting student-led inquiry, dialogue, and critical thinking. Together this approach encourages the $21^{\text {st }}$ Century Skills - the 4Cs: communication, critical thinking, collaboration and creativity, through active, hands-on learning and participation. The Muinín Catalyst participants (students) develop skills in:

- Research

- Critical thinking and inquiry

- Design-thinking

- Problem-finding and solving

- Digital literacy in the 21 st century education (AR/VR)

- Socio-environmental open-source philosophy

- Gamification for Autonomous learning

Currently, global use of resources is unsustainable, with the need to develop new approaches to address our potential future. The ability to bring into being what does not yet exist, or of transforming what does exist into a better version of 
itself [23] will be key to maintaining life on the planet. The project found students were not used to selfdirected learning even when scaffolded (building up learning supports). Activities such as team-building, leadership and effective understanding of project outcomes are often beyond the experience of the students with little to no guidance for educators on how to bridge that gap. With eco-anxiety on the rise and students reporting fear of what their life and environment might look like in the future, with lack of information was not helpful to them [24]. In addition, the students stated they did not talk about environmental issues nor did they believe the adults around them (teachers, parents, local organisations) did not seem to be engaged with issues of climate change, adding further anxiety to their already anxious state. Projects that expand their knowledge, while developing skills that can be applied contribute to a sense of agency and provide a sense of hope [1].

The importance of the project's learning resources were verified within the CoDesRes research and iterated through Muinín Catalyst. The core Problemto-Pitch module, a condensed week-long intensive of delivered as a design challenge, further affirmed the approach.

...one of the benefits I found during the week was I learned how to identify and understand problems that affect me in my day-to-day life.

\section{Extract from Student - Problem to Pitch week-long intensive}

The discussion shows how Muinín Catalyst's place-based STEAM approach instils the foundations for self-organisation and resilience (McKeown et al, 2021). Further, the approach adds to the intrinsic value of the arts to society: enriching our emotional world, encouraging us to see broader perspectives and helping us to make sense of the facts and evidence that explain our world, in a human way. Instead, it cements the skills from art and design in students and teachers who do not choose that subject, in ways that can be transferred to other areas of their life, whether work or personal. Supporting the learners social and emotional learning is another key focus of Muninín Catalyst. Access to students, their opinions on the activities and testing iterations enabled the team to scaffold the resources in ways that were enjoyable and effective.

\section{Teacher Support}

Covid-19 schools' closures highlighted the need to support teachers within their training and CPD to be prepared for rapid changes, particularly in response to $21^{\text {ST }}$ Century Challenges. The current educational curriculum pushes teachers to educate their students only on subjects that will help them on their Junior and Senior leaving certs. This leaves little time to educate in the areas that are seen as required for the $21^{\text {st }}$ century, such as the ability to take action through creative, collaborative, and critical thinking. This focuses students only on learning knowledge, for exams, rather than the need to apply knowledge, in multiple contexts.

The National Council for Curriculum Assessment's pending announcement outlines plans to reform the Senior Cycle and remove the end-ofschool exams by integrating life skills, apprenticeships, voluntary work and increased specialisations selecting subjects and modules orientated to their interests. Although proposals are due to be fleshed out over time, teachers will need require teacher-training. Experience of other professional sectors can be limited, as can the experience of other schools, particularly in rural areas. Our work with teachers has proven to offer teachers tools and methodologies for expanding their own capacity, with the expertise from an interdisciplinary team being embedded in the resources and supported by links to related resources should they be required by the teacher.

... as a science teacher I am used to teaching subject matter and getting students to learn the important points as they might come up in the test but I think using the different methods and resources aids teaching and learning in a number of different ways and affords opportunity for all types of learners to engage and contribute. I have learned lots of new methodologies. It's much more rewarding when the students are interested and engaged and it really helps to have resources to put this scaffolding in place. It allows them freedom to explore their idea while also keeping them on task.

\section{Extract from TY Science Teacher feedback, Coláiste na Sceilge}

Through both phases of the research, we were cognizant of the need to support teachers to integrate place-based STEAM resources that bridge the local and the global in tangible ways. The programme's delivery methods were also developed to offer opportunistic Continual Professional Development (CPD) for teachers through their in-class delivery of the resources. CPD can require additional effort to attend which with an already overloaded time-table, which can be prohibitive. With this in mind, the programme builds capacity by scaffolding facilitation skills while implementing new methodologies, for place-based STEAM and project and inquiry-based learning.

Teachers are keen to implement project and inquiry-based learning but the current teacher training 
and timetables do not support this. While 'off-thepeg' project resources are often used, many of the available project resources are not scaffolded and require tasks that assume an expertise or need more input from the teachers. Such resources can be difficult to implement as they require complex tasks such as, form a team to create an affective awareness campaign or produce a short film.

The expertise (art and design, engineering, technology and various sciences) and additional experience e.g. project management, workshop facilitation, research skills have been embedded within the modules. The practical and experiential learning activities that include content and process aid teacher delivery without subject-specific expertise.

\section{Next Steps}

With no prescribed curriculum in Transition Year, there is strong potential to augment gaps in learning and skills-building. However, students and teachers with a high-status exam focused perspective can struggle to see the benefit from an approach that will not 'tell the student what they need to know' which could be explored more concretely within TY. Depending on the foundational base of 21 st century skills developed in their previous three years of postprimary schooling, there may be limits to the efficacy of one academic year. Situated in a rural area, with population decline increasing as young people look for study and work opportunities elsewhere, we felt it was important for the project to promote the fact that the professional landscape looks far different to what their parents experienced and there is no longer the need to necessarily leave their place to make their future. Opportunities in Ireland, including employment sectors least at risk as stated earlier in the text are shared within the project resources to broaden students and communities' understanding of STEAM opportunities. This with an entrepreneurial approach could offer increased sustainability for rural communities, if the infrastructure is present.

A planned Future of Work seminar event for local parents and students was cancelled due to school closure in March. This event was designed to disseminate information on how the context of work has changed in today's society through a series of talks from local people in industry and a poster exhibition. We plan on pivoting this event into a webinar series for parents and students under the Kerry Education \& Training Board (ETB) as well as featuring our global goals case studies, examples of contemporary cutting-edge projects and research.

With this phase of the Muinín Catalyst project due to end in June 2021, we hope to develop the work through a series of beta trials: initially county-wide, followed by regional and national trials, fundingdependent. We are proposing a hybrid programme, with internal delivery by teachers, linked to service / community learning intensives, augmented by online curriculum supplements including building a teaching and learning supportive network for the 2021/22 academic year. This will involve collaboration with the local Education \& Training Board (ETB) and the TY co-ordinators to develop the pilot activities.

Since, the global pandemic it is even more important to support teachers and students who will, like most of society be in recovery and will be needing a stable year. With this in mind the team have formalised CPD delivery in 2021 and beyond on $21^{\text {st }}$ Century Skills, enabling teachers to augment their teaching skills within Transition Year. To facilitate a supportive environment to engage with change the programme will include live events, clinics webinars, and workshops offered at points throughout the year for teachers (post- post-primary participants (teachers). This will support them to

- Develop awareness of integrating place-based STEAM learning.

- Develop and integrate resources across subject areas.

- Support students to connect local and global issues.

- Be more aware of scaffolded learning and skills development.

- Develop peer-to-peer learning network recognising for change management and post recovery.

By integrating community-based challenges, learners are encouraged to apply 21 st century thinking to local issues with measurable impact by the end of the module. The success of a regional roll out would be a catalyst for a national plan for all Irish ETB's. Covid-19 school closures have further identified the need for structured blended learning that integrates analogue pedagogical principles with available technology as an area for development within teacher training. This has been included within the resources and is proposed for on-going formalised continuing professional development delivery in 2021 / 22.

\section{Conclusion}

Until 2014, the Irish National curriculum had changed little, embedding a knowledge lag and inhibiting contemporary knowledge due to the limitations of the curriculum. The hyper-focus these high-status exam results e.g. Junior and Leaving Cert by all actors: students, parents, education professionals limits the ability to develop future ready students. 
The place-based STEAM approach presented embeds critical thinking, problem solving and collaborative learning through creativity, innovation and research skills within a localised tangible context that is connected to global concerns. This enabled students to apply existing skills in new contexts, gain skills and competencies beyond the curriculum and opportunities to apply these within real world contexts. The resources developed to date employ a wide range of education and training modalities. Additionally, the resources place emphasis on the higher order skills including problem-solving, critical thinking, communication and creativity.

Arguably, the 2030 Agenda and Climate Action should be the lens through which all subjects are taught using an active participatory STEAM inquiry with thematic learning approaches. This would shift the focus from value and belief system towards an integrated pedagogical approach grounded in realworld and scientific data. It is understood that such a radical change to the National Curriculum is unlikely, in the short term, however this could be supplemented by an agile platform that could be updated annually to augment the National Curriculum with contemporary research and field-specific developments, a direction we are also considering.

The research and pilot programme to date has shown the efficacy for students and teachers, of our approach and to this end we are keen to continue to build out the resources and develop the beta-testing programme. The foundations are in place, with the need to become more agile and adaptive and create new platforms where required is clear. The development of Transition Year, with a corresponding learning platform, regularly updated with contemporary research would providing an agile solution to bridging the gaps between the curriculum and real-world knowledge production,

\section{References}

[1] McKeown, A., Hunt,L.,Murphy,J.,Turner,E., and White, R. (2021). Co-designing for rural Resilience through P2P networks and STEAM place-based learning interventions. EPA, Ireland.

[2] Dept. of Education and Science, 'Rules and Programme for Secondary Schools'. (2004). https://www.gov.ie/en/ publication/a07bb6-rules-and-programme-for-secondary-sc hools/ (Access Date: 12 April 2021).

[3] Walshe, J. "Schools cutting back on class time get a ticking off in report". Irish Independent. (22 June 2007). https://www.independent.ie/education/latest-news/schoolscutting-back-on-class-time-get-a-ticking-off-in-report-740 500.html_(Access Date: 24 January 2021).

[4] McNulty, A. 'Councillor supports 'scrapping' of 'doss' Transition Year' The Mayo News. (2011). https://www.ma yonews.ie/index.php?option=com_content $\&$ view $=$ article $\&$ id=13818: councillor-supports-scrapping-of-doss-transition -year. (Accessed Date: 12 April 2021).

[5] National Council for Curriculum and Assessment. (2012). Mathematics Syllabus: Foundation, Ordinary and Higher Level, Department of Education and Skills, available: www.ncca.ie (Access Date: 28 February 2021).

[6 National Council for Curriculum and Assessment (NCCA). (2018). Annual Report 2017, NCCA, Ireland.

[7] McKeown, A. (2020). Towards Developing Equitable Economies, The concept of Oikos in Placemaking in Cara Courage, Tom Borrup, Maria Rosario Jackson, Kylie Legge, Anita McKeown, Louise Platt, Jason Schupbach. The Placemaking Handbook Routledge, London.

[8] McKeown, A. (2015). Cultivating permaCultural resilience: towards a creative placemaking critical praxis. Unpublished PhD Thesis, National College of Art and Design. Ireland.

[9] National Council for Curriculum and Assessment (NCCA). (2020). Interim report of review of senior cycle education, NCCA, Dublin. https://ncca.ie/media/4025/seni or-cycle-review-interim-report-july-2019.pdf (Access Date: 7 September, 2019).

[10] Organisation for Economic Cooperation and Development. (2020). Education in Ireland: An OECD Assessment of the Senior Cycle Review, Implementing Education Policies, https://www.oecdilibrary.org/sites/1f7 78499en/index.html?itemId=/content/component/1f778499 -en (Access Date: 4 June 2021).

[11] Crowley, F. and Doran, J. 'Automation and Irish towns: who's most at risk?'. https://www.ucc.ie/en/media/project sandcentres/srerc/SRERCWP2019-1_upload.pdf (Access Date: 21 March 2021).

[12] Department of Education and Skills (DES). (2015). Ireland's National Skills Strategy 2025 Government of Ireland, Dublin.

[13] National Spatial Strategy (NSS). (2000). Centre for Local and Regional Studies - NUI Maynooth and Brady Shipman Martin.

[14] McKeown, A. (2018). Tracing the Evolution of an Arts-led Place-based Syllabus for STEAM: The Beautiful Midden Field School Syllabus, in The STEAM revolution: Transdisciplinary Approaches to Science, Technology, Engineering, Arts, Humanities and Mathematics - eds De La Garza, A and Travis C, Springer Publishing, NYC USA (2020:333)

[15] Rose, C and Smith, B. (2011). Workshop: Bridging STEM to STEAM: Developing New Frameworks for Art/Science Pedagogy, Rhode Island School of Design, Rhode Island.

[16] Wellcome. (2017). Trust The Arts https://wellcome. ac.uk/what-we-do/our-work/arts (Access Date: 10 April 2020). 
[17] White, R 'The Classroom Around Us: utilising place in language learning' ELT Ireland https://www.eltireland.com/event-speaker-slides (Access Date: 2 December 2020).

[18] Bird, A. "Evaluating the Impact of Burrenbeo Trust: Place-based Learning and Community Stewardship" Ireland; Irish Research Council 2020, 2008 - 2018.

[19] Omsin, J. and Amornrat Watthanathorn, A. (2015). Place-Based Education: The Development of Good Citizenship in Youth Based on Community Contexts, Department of Education, Faculty of Education, Naresuan University 2015.

[20] Casey, Edward S. (1996). "How to Get from Space to Place in a Fairly Short Stretch of Time: Phenomenological Prolegomena." In Senses of Place, edited by Steven Feld and Keith H Basso.Santa Fe, N.M.; [Seattle]: School of American Research Press ; Distributed by the University of Washington Press. (9).

[21] What is Design Thinking IDEO-U Last Modified 2021 https://www.ideou.com/blogs/inspiration/what-is-designthinking (Access Date: 3 May 2021).

[22] What is Design Thing and Why is it so Popular? Interaction Design Last modified Sept (2020). https://www.interaction-design.org/literature/article/whatis-design-thinking-and-why-is-it-so-popular (Access Date: 12 January 2021).

[23] Rockström, J., W. Steffen, K. Noone, ^. Persson, F.S. Chapin, III, E. Lambin, T.M. Lenton, M. Scheffer, C. Folke, H. Schellnhuber, B. Nykvist, C.A. De Wit, T. Hughes, S. van der Leeuw, H. Rodhe, S. Sörlin, P.K. Snyder, R. Costanza, U. Svedin, M. Falkenmark, L. Karlberg, R.W. Corell, V.J. Fabry, J. Hansen, B. Walker, D. Liverman, K. Richardson, P. Crutzen, and J. Foley, (2009). Planetary boundaries: Exploring the safe operating space for humanity. Ecol. Soc., 14, no. 2, 32.

[24] Creative Ireland. (2017). Clár Éire Ildánach The Creative Ireland Programme End of Year Report. https://www.creativeireland.gov.ie/app/uploads/2019/12/C reative-Ireland-Programme-End-of-Year-Report-2017.pdf (Access Date: 13 February, 2021). 